\title{
NORTH-EASTERNMOST RECORD OF HALOSAURUS OVENII (ACTINOPTERYGII: NOTACANTHIFORMES: HALOSAURIDAE) IN THE MEDITERRANEAN SEA, WITH NOTES ON ITS BIOLOGY
}

\author{
Antonio PAIS ${ }^{1}$, Paolo MERELLA ${ }^{2}$, Maria Cristina FOLLESA ${ }^{3}$, and Hiroyuki MOTOMURA ${ }^{4}$ \\ ${ }^{1}$ Sezione di Acquacoltura e Gestione delle Risorse Acquatiche, Dipartimento di Scienze Zootecniche, \\ Università di Sassari, Sassari, Italy \\ ${ }^{2}$ Sezione di Parassitologia e Malattie Parassitarie, Dipartimento di Biologia Animale, \\ Università di Sassari, Sassari, Italy \\ ${ }^{3}$ Dipartimento di Biologia Animale ed Ecologia, Università di Cagliari, Viale Poetto 1, 09126 Cagliari, Italy \\ ${ }^{4}$ The Kagoshima University Museum, 1-21-30 Korimoto, Kagoshima 890-0065, Japan
}

Pais A., Merella P., Follesa M.C., Motomura H. 2009. North-easternmost record of Halosaurus ovenii (Actinopterygii: Notacanthiformes: Halosauridae) in the Mediterranean Sea, with notes on its biology. Acta Ichthyol. Piscat. 39 (1): 33-37.

\begin{abstract}
A single adult female specimen of Halosaurus ovenii Johnson, 1864 was captured by trammel nets at a depth of about $200 \mathrm{~m}$ off the coast of Arbatax (Sardinia, Italy) in early April 2007. Macroscopic and microscopic analysis of the gonad showed a postspawning ovary. This is the fourth documented capture of this fish in the Mediterranean Sea, representing the north-easternmost record for this species in this geographic area. Furthermore, the present specimen was fished at the shallowest depth ever recorded before.
\end{abstract}

Keywords: Halosaurus ovenii, new record, Mediterranean, Sardinia

According to Froese and Pauly (2008), 10 species belong to the genus Halosaurus Johnson, 1864 (Notacanthiformes: Halosauridae), 3 of which commonly occur in the eastern Atlantic: H. guentheri Goode et Bean, 1896; H. johnsonianus Vaillant, 1888; and H. ovenii Johnson, 1864. The latter species is a benthopelagic fish that lives at bathyal depths ranging from 440 to $1700 \mathrm{~m}$ (Sulak 1986). It is an amphiatlantic fish commonly present off Madeira, the Canaries, the Azores and the western African coast from Morocco to South Africa (Sulak 1990), but it was also recorded off the coast of Portugal (Costa and Reiner 1978). In the western Atlantic its geographical distribution is well documented from the Caribbean and the Gulf of Mexico, and off the Lesser Antilles (Sulak 1990, Smith 2002). This fish is extremely rare in the Mediterranean Sea, where Golani et al. (2002) considered it as an exotic species. Its first record in this basin was reported by Dieuzeide (1963) from off the Habibas Islands (Algeria, western Mediterranean) where, in 1960, a single specimen was captured at $550 \mathrm{~m}$ depth. Cau and Deiana (1979) documented the occurrence of this species off Capo Teulada (Sardinia, Italy, central western Mediterranean) at $620 \mathrm{~m}$ depth. Finally, D'Onghia et al. (2004) captured one specimen (229 mm TL) off the Balearic Islands, at $2800 \mathrm{~m}$ depth, the deepest record for this species. The capture of another specimen of $H$. ovenii off the eastern coast of Sardinia represented a noteworthy opportunity to collect additional information on its geographical distribution and biology.

On 3 April 2007, one adult specimen of $H$. ovenii was captured by trammel nets 1.5 miles off the port of Arbatax (Sardinia, central western Mediterranean, lat $39^{\circ} 57.6^{\prime} \mathrm{N}$, long $09^{\circ} 44.3^{\prime} \mathrm{E}$ ) on a muddy bottom at a depth of about $200 \mathrm{~m}$ (Fig. 1). The fish was photographed (Fig. 2), frozen at $-20^{\circ} \mathrm{C}$, and in the laboratory it was identified to species according to Sulak (1986).

Its stomach contents were weighed, examined, and then stored in $70 \%$ ethanol. After sex determination (female), the maturity stage of the ovary was assessed macroscopically according to Holden and Raitt (1974), and then the gonad was fixed in 5\% buffered formalin for subsequent histological analysis. Afterwards, the ovary was dehydrated in an ascending ethanol series, embedded in resin, and semi-thin sections of $3 \mathrm{~mm}$ were stained with sodium iodoeosine and toluidine blue following Dominici's method modified for methacrylate (Mazzi 1977). The iden-

\footnotetext{
${ }^{*}$ Correspondence: Dr Antonio Pais, Sezione di Acquacoltura e Gestione delle Risorse Acquatiche, Dipartimento di Scienze Zootecniche, Università di Sassari, Via E. De Nicola 9, 07100 Sassari (Italy), phone: +39 079 229345, fax: +39 079 229302, e-mail: pais@uniss.it
} 


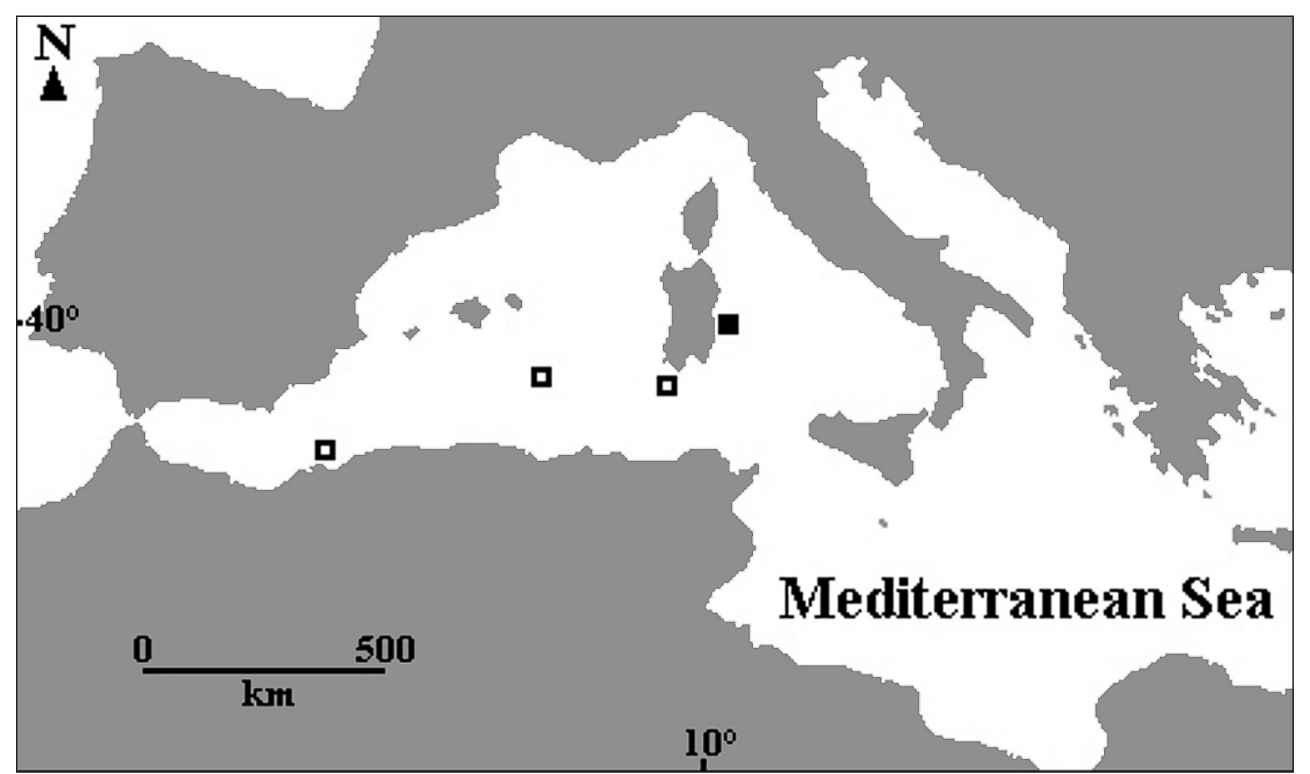

Fig. 1. Map of records of Halosaurus ovenii in the Mediterranean. Black square = presently described record; hollow squares $=$ previous records

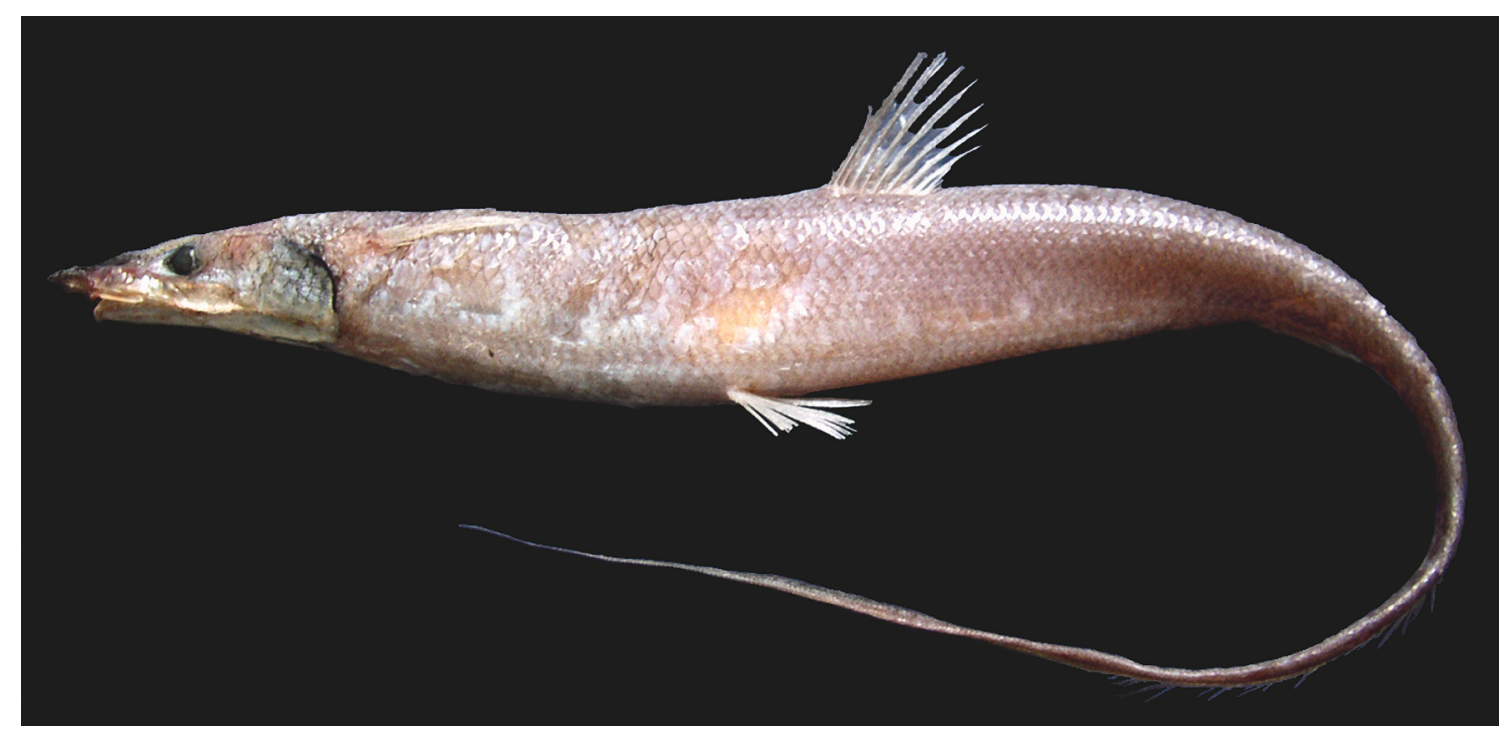

Fig. 2. Halosaurus ovenii, DSZ-04/07, $470 \mathrm{~mm}$ TL, Sardinia, Western Mediterranean, $200 \mathrm{~m}$ depth

tification of the oocyte developmental stages was carried out using an optical microscope, according to the scale proposed by Forberg (1982). Gonadic maturity stages were determined on the basis of the relative abundance of oocytes cells in the more advanced stage of development. The diameter of nucleated oocytes was measured by means of a graduated ocular.

Body surface, mouth, gills, body cavity and all internal organs were examined for metazoan parasites. Fresh scrapings of the organs were also observed microscopically for protozoan parasites. Finally, the fish was deposited in the ichthyological collection of the Department of Animal Science at the University of Sassari (registration code DSZ-04/07).

The fish was a female of $470 \mathrm{~mm}$ total length and $92.9 \mathrm{~g}$ total weight. Morphometric and meristic characters of the present specimen and of those formerly reported from the Mediterranean are given in Table 1. The ovary appeared flaccid and whitish in colour, with many visible eggs. It was located just after the liver, composed by 2 distinct lobes originating proximally at about $1 / 5$ of its length and extending posteriorly up to $3 / 4$ of the body cavity. Macroscopic analysis revealed that it was at a post-spawning stage (stage 7 of Holden and Raitt scale). Subsequent histological analysis showed the presence of few mature oocytes [translucent $(\mathrm{T})$, mean diameter $940 \pm 39.74 \mu \mathrm{m}$, ripe egg stage by Forberg (1982)]; atresic oocytes (ATR); and post-ovulatory follicles (POF) (Fig. 3). The stomach and intestine contained only remains of organic matter and neither protozoan nor metazoan parasites were detected.

Halosaurus ovenii was first captured in the Mediterranean Sea only in 1960 (Dieuzeide 1963). This 
Table 1

Morphometric and meristic data of Halosaurus ovenii specimens recorded in the Mediterranean Sea

\begin{tabular}{|c|c|c|c|c|}
\hline & Character & This study & $\begin{array}{c}\text { Dieuzeide } \\
(1963)\end{array}$ & $\begin{array}{c}\text { Cau and Deiana } \\
\text { (1979) }\end{array}$ \\
\hline \multirow{10}{*}{ 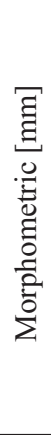 } & Total length [TL] & 470 & - & 520 \\
\hline & Gnathoproctal length & 21 & - & - \\
\hline & Body height & 35 & $1 / 14 \mathrm{TL}$ & 38 \\
\hline & Head length [HL] & 56 & $1 / 8 \mathrm{TL}$ & 62.5 \\
\hline & Snout length & 23 & - & - \\
\hline & Predorsal length & 142 & - & 157 \\
\hline & Preanal length & 225 & - & - \\
\hline & Eye diameter length [ED] & $9.2-9.5$ & $1 / 5 \mathrm{HL}$ & 13.3 \\
\hline & Eye diameter height & $6.5-6.7$ & - & 8.0 \\
\hline & Interorbital width & 4.7 & $1 / 2 \mathrm{ED}$ & - \\
\hline \multirow{7}{*}{$\frac{.0}{D_{0}^{n}}$} & Dorsal fin rays & $\mathrm{I}+10$ & $\mathrm{I}+10$ & $\mathrm{I}+10$ \\
\hline & Anal fin rays & $>190$ & 191 & 152 \\
\hline & Pectoral fin rays & $\mathrm{I}+14$ & $\mathrm{I}+10$ & $\mathrm{I}+12$ \\
\hline & Ventral fin rays & $\mathrm{I}+7-8$ & $\mathrm{I}+9$ & $\mathrm{I}+9$ \\
\hline & Gill rakers 1 st arch & $12(9+3)$ & - & - \\
\hline & Lateral line scales anterior to anus & $66-67$ & - & - \\
\hline & Pyloric caeca & 11 & 12 & 11 \\
\hline
\end{tabular}

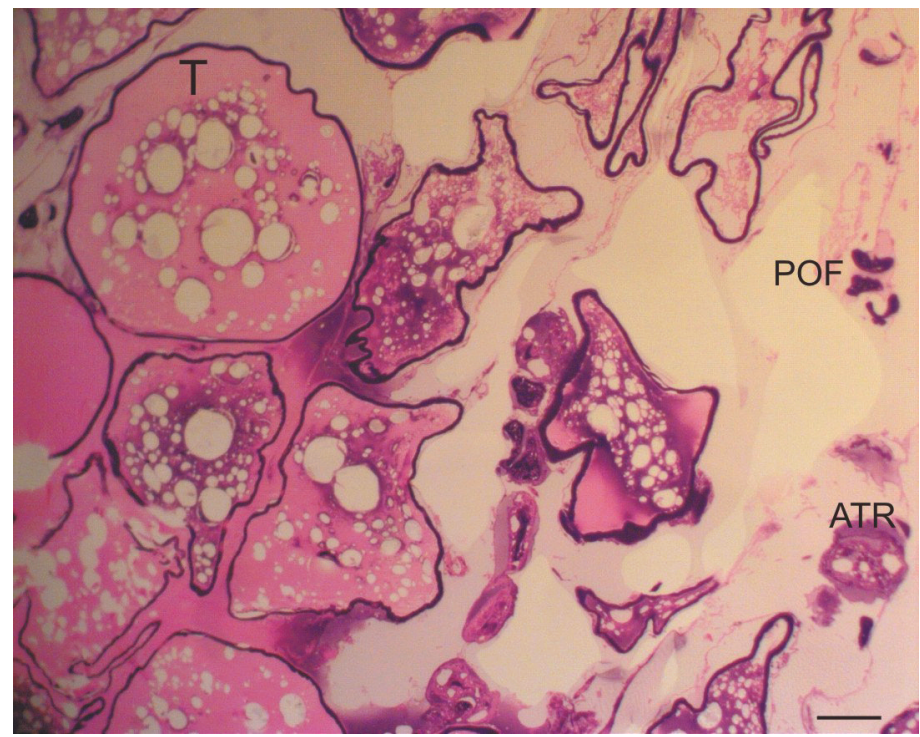

Fig. 3. Histological stage of Halosaurus ovenii ovary: translucent oocyte (T), post-ovulatory follicle (POF) and atresic oocyte (ATR); scale bar $=250 \mu \mathrm{m}$

late record probably led Quignard and Tomasini (2000) to consider it as a recent migrant and not just a rare species in this geographical area. In any case, the present capture confirms its presence also in the central-western part of the basin and corresponds to its north-easternmost occurrence in the Mediterranean. As the present specimen was fished at the shallowest depth ever recorded before (i.e., about $200 \mathrm{~m}$ ), this new record shows an extremely wide bathymetric range for this species, i.e., from $200 \mathrm{~m}$ down to $2800 \mathrm{~m}$ (D'Onghia et al. 2004). The female examined appeared at a post-spawning stage, in accordance with the observations reported by Cau and Deiana (1979) for another $H$. ovenii specimen captured in the same period of the year. The presence of POFs in the gonadic tissue was a further confirmation that the ovary was quiescent (Cinquetti and Rinaldi 1987, Yoneda et al. 1998).

The specimen examined was totally free of parasites. There are few reports of parasites from members of the family Halosauridae, the only ones are from Aldrovandia oleosa Sulak, 1977 (cf. Sulak 1977) and Halosauropsis macrochir (Günther, 1878) (cf. Klimpel et al. 2001 and references therein, Klimpel et al. 2008), and no parasite had been reported from Halosaurus spp. Moreover, Boxshall (1998), in a broad study on host specificity 
in copepod parasites of deep-sea fishes, observed that copepods had failed to colonise Halosaurus spp. from the North Atlantic, in spite of their relative abundance in deep sea habitat. The absence of parasites in the examined host (although limited to a single specimen) seems to confirm some drawback in the success of parasite on this genus, notwithstanding these fish inhabit the bathyal grounds, where the diversity of parasites is relatively high (Marcogliese 2002, Klimpel et al. 2006). Finally, a further mechanism that could explain the absence of parasites is the enemy release hypothesis (ERH). It points out that introduced species usually invade new areas without their natural parasites or they lose them in the new habitat (Colautti et al. 2004). This will suggest that $H$. ovenii should be considered as exotic to the Mediterranean Sea and/or that the examined host was caught at a shallower depth of the natural range of the species. But caution should be considered in the uncritical acceptance of ERH, as recently reported by Pais et al. $(2007,2008)$ and Merella et al. (2008), for Atlantic and Lessepsian migrants from the same geographical area.

\section{ACKNOWLEDGEMENTS}

The authors are especially grateful to Silverio Calisi, skipper of the F/V SBRIGLIO of Arbatax, to Mario and Simone Demelas for providing the specimen and useful information on the catch site, and to two anonymous reviewers for their critical comments and valued suggestions.

\section{REFERENCES}

Boxshall G.A. 1998. Host specificity in copepod parasites of deep-sea fishes. Journal of Marine Systems 15: 215-223. DOI: 10.1016/S0924-7963(97)00058-4.

Cau A., Deiana A.M. 1979. Prima segnalazione di Halosaurus ovenii Johnson, 1863 nei mari italiani. Quaderni della Civica Stazione Idrobiologica di Milano 7: 127-130. [In Italian.]

Cinquetti R., Rinaldi L. 1987. Change in the gonadal histology of Padogobius martensi (Pisces: Gobiidae) during the reproductive cycle. Italian Journal of Zoology 54: 233-241. DOI: 10.1080/11250008709355589.

Colautti R.I., Ricciardi A., Grigorovich I.A., MacIsaac H.J. 2004. Is invasion success explained by the enemy release hypothesis? Ecology Letters 7: 721-733. DOI: 10.1111/ /j.1461-0248.2004.00616.x.

Costa M.J., Reiner F. 1978. First record of Halosaurus ovenii Johnson, 1863 and Echiostoma barbatum Lowe, 1843 (Pisces, Halosauridae and Melanostomatidae) off Portugal. Boletim da Sociedade Portuguesa de Ciências Naturais 18: 43-46.

Dieuzeide R. 1963. Halosaurus oweni Johnson rencontré pour la première fois en Méditerranée. Recueil des Travaux de la Station Marine d'Endoume 28: 117-119.

D’Onghia G., Lloris D., Politou C.-Y., Sion L., Dokos L. 2004. New records of deep-water teleost fish in the Balearic Sea and Ionian Sea (Mediterranean Sea). Scientia Marina 68 (Suppl 3): 171-183. DOI: 10.3989/scimar.2004.68s3171.

Forberg K.G. 1982. A histological study of development of oocytes in capelin, Mallotus villosus villosus (Müller).
Journal of Fish Biology 20: 143-154. DOI: 10.1111/j.1095-8649.1982.tb03915.x.

Froese R., Pauly D. 2008. FishBase. www.fishbase.org, version (02/2008).

Golani D., Orsi Relini L., Massutí E., Quignard J.P. 2002. CIESM Atlas of exotic species in the Mediterranean. Vol. 1 Fishes. Briand F. (ed.) CIESM Publications, Monaco.

Holden M.J., Raitt D.F.S. 1974. Manual of Fisheries Science. Part 2, Methods of resource investigation and their application. FAO Fisheries Technical Paper 115. FAO, Rome.

Klimpel S., Palm H.W., Busch M.W., Kellermanns E. 2008. Fish parasites in the bathyal zone: the halosaur Halosauropsis macrochir (Günther, 1878) from the MidAtlantic Ridge. Deep Sea Research Part II: Topical Studies in Oceanography 55: 229-235. DOI: 10.1016/ /j.dsr2.2007.09.006.

Klimpel S., Palm H.W., Busch M.W., Kellermanns E., Rückert S. 2006. Fish parasites in the Arctic deep-sea: Poor diversity in pelagic fish species vs. heavy parasite load in a demersal fish. Deep Sea Research Part I: Oceanographic Research Papers 53: 1167-1181. DOI: 10.1016/ /j.dsr.2006.05.009.

Klimpel S., Seehagen A., Palm H.W., Rosenthal H. 2001. Deep-water metazoan fish parasites of the world. Logos Verlag, Berlin.

Marcogliese D.J. 2002. Food webs and the transmission of parasites to marine fish. Parasitology 124: 83-99. DOI: 10.1017/S003118200200149X.

Mazzi V. 1977. Manuale di tecniche istologiche e istochimiche. Piccin, Padova. [In Italian.]

Merella P., Farjallah S., Pais A., Follesa M.C., Garippa G. 2008. Parasites of non-indigenous fish species in the Mediterranean Sea: two case reports. P. 164. In: Xth European Multicolloquium of Parasitology (EMOP 10) Program and Abstract Book, 24-28 August 2008, Paris, France.

Pais A., Merella P., Follesa M.C., Garippa G. 2007. Westward range expansion of the Lessepsian migrant Fistularia commersonii (Fistulariidae) in the Mediterranean Sea, with notes on its parasites. Journal of Fish Biology 70: 269-277. DOI: 10.1111/j.1095-8649.2006.01302.x.

Pais A., Merella P., Follesa M.C., Garippa G., Golani D. 2008. New data on Gaidropsarus granti (Regan, 1903) (Gadiformes: Lotidae) from the Mediterranean Sea, with emphasis on its parasites. Scientia Marina 72: 461-468. DOI: $10.3989 /$ scimar.2008.72n3461.

Quignard J.P., Tomasini J.A. 2000. Mediterranean fish biodiversity. Biologia Marina Mediterranea 7: 1-66.

Smith D.G. 2002. Halosauridae. Pp. 685-687. In: Carpenter K.E. (ed.) The living marine resources of the Western Central Atlantic. Vol. 2: Bony fishes part 1 (Acipenseridae to Grammatidae). FAO, Rome.

Sulak K.J. 1977. Aldrovandia oleosa, a new species of the Halosauridae, with observations on several other species of the family. Copeia 1: 11-20.

Sulak K.J. 1986. Halosauridae. Pp. 593-598. In: Whitehead P.J.P., Bauchot M.L., Hureau J.C., Nielsen J., Tortonese E. (eds.) Fishes of the North-eastern Atlantic and the Mediterranean, Vol. 2. UNESCO, Paris. 
Sulak K.J. 1990. Halosauridae. Pp. 126-132. In: Quero J.C., Hureau J.-C., Karrer C., Post A., Saldanha L. (eds.) Checklist of the Fishes of the Eastern Tropical Atlantic (CLOFETA), Vol. 1. JNICT, Lisbon, SEI, Paris, UNESCO, Paris.

Yoneda M., Tokimura M., Fujita H., Takeshita N., Takeshita K., Matsuyama M., Matsuura S. 1998. Reproductive cycle and sexual maturity of the anglerfish
Lophiomus setigerus in the East China Sea with a note on specialized spermatogenesis. Journal of Fish Biology 53: 164-178. DOI: 10.1111/j.1095-8649.1998.tb00118.x.

Received: 17 May 2008 Accepted: 4 December 2008 Published electronically: 20 May 2009 